\title{
The New Human Babesia sp. FR1 Is a European Member of the Babesia sp. MO1 Clade
}

\author{
Claire Bonsergent ${ }^{1, *}$, Marie-Charlotte de Carné ${ }^{2}$, Nathalie de la Cotte ${ }^{1}$, François Moussel ${ }^{3}$, Véronique Perronne ${ }^{2}$ \\ and Laurence Malandrin ${ }^{1, *}$
}

check for

updates

Citation: Bonsergent, C.; de Carné, M.-C.; de la Cotte, N.; Moussel, F.; Perronne, V.; Malandrin, L. The New Human Babesia sp. FR1 Is a European Member of the Babesia sp. MO1 Clade. Pathogens 2021, 10, 1433. https://doi.org/10.3390/pathogens 10111433

Academic Editors: Estrella Montero, Jeremy Gray, Cheryl Ann Lobo and Luis Miguel González

Received: 1 October 2021

Accepted: 30 October 2021

Published: 4 November 2021

Publisher's Note: MDPI stays neutral with regard to jurisdictional claims in published maps and institutional affiliations.

Copyright: (c) 2021 by the authors. Licensee MDPI, Basel, Switzerland. This article is an open access article distributed under the terms and conditions of the Creative Commons Attribution (CC BY) license (https:/ / creativecommons.org/licenses/by/ $4.0 /)$.
1 BIOEPAR, INRAE, Oniris, 44300 Nantes, France; nathalie.delacotte@oniris-nantes.fr

2 Service de Maladies Infectieuses et Tropicales, Hôpital F. Quesnay, 78200 Mantes-la Jolie, France; mcdecarne@ch-versailles.fr (M.-C.d.C.); veronique.perronne@aphp.fr (V.P.)

3 Laboratoire de Biologie Médicale, Hôpital F. Quesnay, 78200 Mantes-la-Jolie, France; f.moussel@ch-mantes-la-jolie.fr

* Correspondence: claire.bonsergent-guillou@inrae.fr (C.B.); laurence.malandrin@inrae.fr (L.M.)

\begin{abstract}
In Europe, Babesia divergens is responsible for most of the severe cases of human babesiosis. In the present study, we describe a case of babesiosis in a splenectomized patient in France and report a detailed molecular characterization of the etiological agent, named Babesia sp. FR1, as well as of closely related Babesia divergens, Babesia capreoli and Babesia sp. MO1-like parasites. The analysis of the conserved $18 \mathrm{~S}$ rRNA gene was supplemented with the analysis of more discriminant markers involved in the red blood cell invasion process: rap-1a (rhoptry-associated-protein 1) and ama-1 (apical-membrane-antigen 1). The rap-1a and ama-1 phylogenetic analyses were congruent, placing Babesia sp. FR1, the new European etiological agent, in the American cluster of Babesia sp. MO1-like parasites. Based on two additional markers, our analysis confirms the clear separation of $B$. divergens and B. capreoli. Babesia sp. MO1-like parasites should also be considered as a separate species, with the rabbit as its natural host, differing from those of B. divergens (cattle) and B. capreoli (roe deer). The natural host of Babesia sp. FR1 remains to be discovered.
\end{abstract}

Keywords: Babesia divergens; Babesia sp. MO1; Babesia capreoli; rap-1a; ama-1; phylogeny

\section{Introduction}

Babesiosis is a tick-borne disease affecting a wide range of vertebrates worldwide. Symptoms of this disease are caused by the intraerythrocytic development of Protozoa of the genus Babesia, causing fever, jaundice, hemoglobinuria and anemia, possibly leading to death, depending on the Babesia species and the host. About one hundred species of Babesia have been described and transmission of the parasite between hosts occurs almost exclusively through Ixodid tick bites [1].

Even though humans are not natural hosts of Babesia, human infections caused by several different species of Babesia have been reported worldwide. Babesia microti, B. duncani (WA1) [2] and to a lesser extent $B$. divergens-like (Babesia sp. MO1 clade) [3] have been reported to cause disease in humans in the USA. The most prevalent species is $B$. microt $i$ responsible of infections that follow a relatively benign course [4]. In Asia, a few cases have recently been reported, caused by $B$. divergens-, B. venatorum- or B. crassa-like strains [5-7].

In Europe, the first case of human babesiosis was described in 1957 in Croatia [8,9]. In 1997, a review on human babesiosis in Europe reported 24 cases in splenectomized $(20 / 24)$ and non-splenectomized (4/24) patients, $46 \%$ of which were fatal even in nonsplenectomized patients (2/4) [10]. At that time, the molecular diagnosis of the parasite species was lacking and cases were attributed to $B$. divergens based on morphological and/or serological grounds. A few years later, molecular analysis revealed a new etiological babesiosis agent, Babesia sp. EU1, which was found to be responsible for human cases in Austria, Italy [11], Germany [12] and Sweden [13]. Human babesiosis cases due to $B$. 
microti have been reported in Europe but usually they are imported cases from the USA [14], with only one autochtonous case reported to date in Germany [15]. Severe sporadic cases are usually attributed to $B$. divergens [16-24]. However, molecular confirmation of the species is not always undertaken [25-27]. Serological analysis and morphology on smears are not sufficient to ascertain $B$. divergens as the etiological agent. Even for specialists, the morphological distinction of $B$. divergens from Babesia sp. EU1 on smears is impossible [11,12]. Confirmed cases of babesiosis due to B. divergens can remain serologically negative [28-30], and serology can be confusing due to dot-like reactivity patterns of most human positive sera, concentrated at the apical pole of the parasite [31]. This reactivity pattern was confirmed with a serum from a clinically and molecularly confirmed human $B$. divergens case in Finland [18,31].

The phylogenetic group including $B$. divergens gathers different named or as yet unnamed species that are very closely related, and we will refer to this group as $B$. divergenslike. $B$. divergens is indeed closely related and can be confused with $B$. capreoli, a parasite frequently found in roe deer in Europe, due to their high 18S rRNA sequence relatedness [32,33]. However, the conservation of three base differences in this gene between isolates of $B$. divergens (pathogen of cattle/humans) and isolates of B. capreoli (pathogen of roe deer), linked to different in vitro host ranges, allowed the delineation of these two species [33]. Babesia sp. MO1 also belongs to this phylogenetic group, and is responsible for a small number of severe or fatal human babesiosis in splenectomized patients in the USA [3,34-36]. Cottontail rabbits are the natural hosts of Babesia sp. MO1 [37,38]. In vitro cultivation features as well as in vivo experimental infections demonstrated the incapacity of this genetic variant to infect cattle, and, combined with $18 \mathrm{~S}$ rRNA sequence differences, led to its species differentiation from $B$. divergens and the provisional name Babesia sp. MO1 [39-41].

In splenectomized patients, babesiosis due to $B$. divergens is fulminant with symptoms that appear within 1-3 weeks post infection, with persistent high fevers and headaches, followed by severe intravascular hemolysis, hemoglobinuria, and jaundice. Babesiosis in splenectomized patients is often fatal in Europe, as diagnosis and therefore adequate treatment are often delayed due to uncharacteristic flu-like symptoms and the infrequency of cases [42,43]. Severe symptoms and fatal cases also occur in non-splenectomized patients with known or unknown predispositions such as splenic dysfunction or a rudimentary spleen $[18,19]$. In immunocompetent patients, $B$. divergens infection is associated with flu-like symptoms shortly after a tick bite [29] or may remain asymptomatic [44].

In the present study, we describe an unusually mild babesiosis in an asplenic patient in France, originally suspected to be caused by B. divergens. Intrigued by the unusual course of infection, we carried out the molecular characterization of the responsible agent. As the $18 \mathrm{~S}$ rRNA gene is rather conserved within the $B$. divergens taxonomic group, and therefore not sufficiently informative, we supplemented the molecular description with two additional and more variable markers: the apical membrane antigen 1 (ama-1) and the rhoptryassociated-protein-1a (rap-1a) genes. Molecular characterization and polymorphism of these two genes were also analyzed for different members of the Babesia divergens-like phylogenetic group, including the phylogenetically closely related B. capreoli and Babesia sp. AR1 identical to Babesia sp. MO1 but from a patient in Arkansas [35], and compared to available sequences of these genes for $B$. divergens.

\section{Results}

\subsection{Babesia sp. FR1: Report of the Clinical Case}

A 56-year-old man came into the emergency room with a suspected meningitidis syndrome. He was Caucasian and his only notable antecedent was a splenectomy in 2001 following a skiing accident (pneumococcal vaccine administered in November 2016, no Haemophilus nor meningococcal vaccines).

The patient stayed on the Île de Ré from 4 August 2017 to 24 August, then from 29 August to 3 September, at a house located at the edge of a forest. He also stayed in Béthune from 25 August to 28 August. He had a fever for 2 weeks associated with 
headaches. He then developed severe asthenia, sweats, tachypnea, myalgia, and elbow, shoulder, and knee arthralgia.

The first blood test (5 September) revealed thrombopenia: 99 giga/L, CRP $65.6 \mathrm{mg} / \mathrm{L}$, ASAT 82U/L, ALAT 73U/L. On 9 September 2017, he developed vomiting, photophobia and a stiff neck, which led to the patient being transferred to hospital (11 September). Nothing specific was revealed by non-injected brain CT. Lumbar puncture was normal, and culture was sterile. Blood tests revealed the following: platelets 71 giga/L, leukocytes 8.40 giga/L (PNN 7.056 giga/L, lymphocytes 0.670 giga/L), hemoglobin $14.4 \mathrm{~g} / \mathrm{dL}$, ASAT $57 \mathrm{U} / \mathrm{L}$, ALAT $61 \mathrm{U} / \mathrm{L}$, GGT $128 \mathrm{U} / \mathrm{L}$, PAL $188 \mathrm{U} / \mathrm{L}$, normal kidney function.

On 12 September, when admitted to the infectious disease unit, clinical examination showed fever, asthenia, and non-significant axillary lymph nodes. The same day, a blood smear showed red blood cells with Babesia corpuscles inside, reaching a parasitemia of $3.7 \%$ (Figure 1). Blood analysis revealed thrombopenia ( 60 giga/L) and hemolysis signs without anemia (Hb $14.4 \mathrm{~g} / \mathrm{dL}$, LDH $890 \mathrm{U} / \mathrm{L})$. Lyme, HCV and HBV serologies were all negative, and protein electrophoresis was normal.

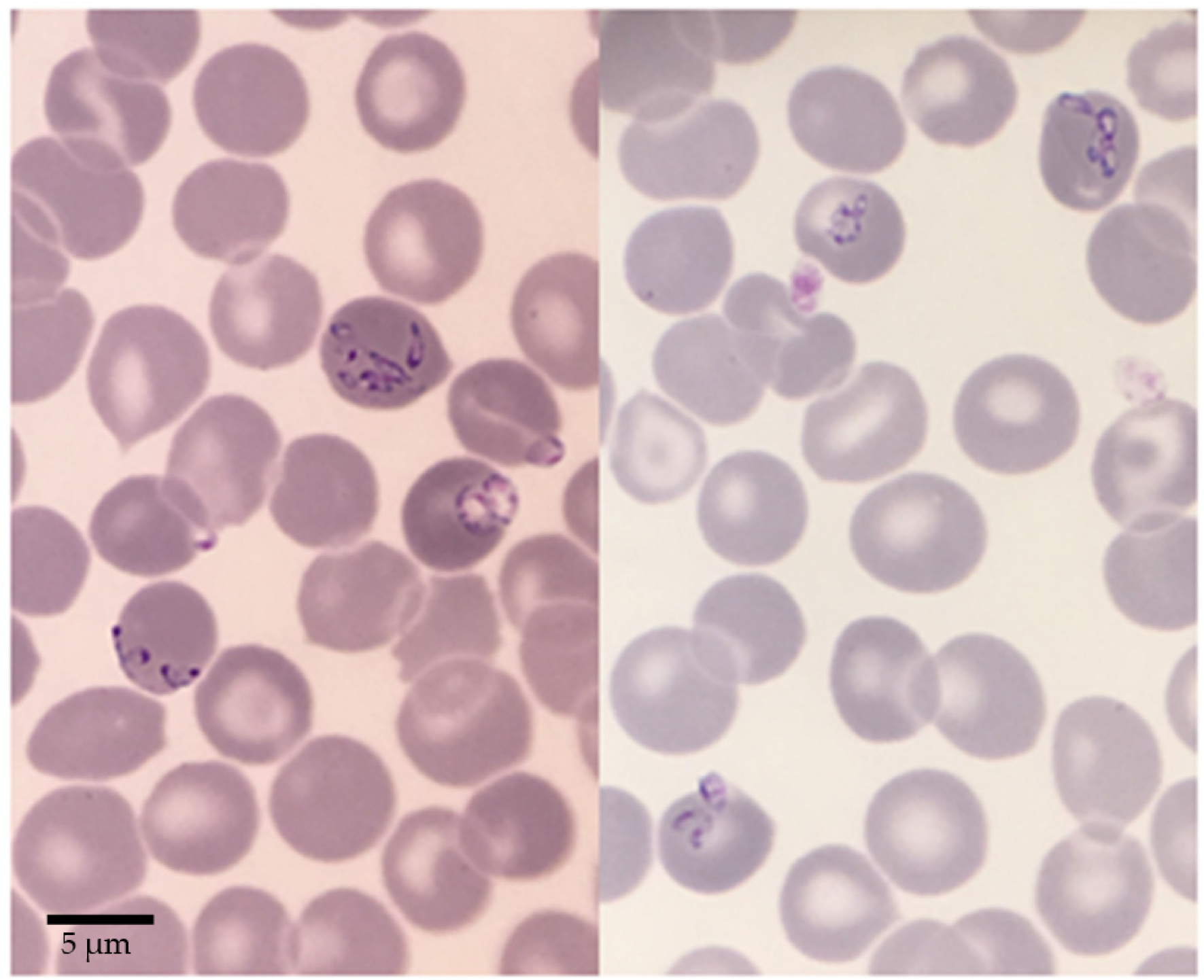

Figure 1. Blood smears of Babesia sp. FR1 used to diagnose the Babesia divergens-like infection of the patient. Human red blood cells infected with dividing pear shaped merozoites are visible, as well as rounded trophozoites. Bar $=5 \mu \mathrm{m}$. 
Antimicrobial therapy was undertaken on the same day with Atovaquone (750 mg/12h) and Azithromycine (500 mg on day 1 then $250 \mathrm{mg}$ per day). The patient rapidly felt better with apyrexia and disappearance of all symptoms. On 14 September, parasites were still detected on the blood smear and cytolysis was persistent.

Diagnosis of a $B$. divergens-like infection was confirmed by serology (IFAT with $B$. divergens antigen) with a titer of 1:1024 and by PCR on the 18S rRNA gene as described in materials and methods. Sequencing of the amplified $18 \mathrm{~S}$ rRNA gene portion confirmed that the responsible agent was closely related to $B$. divergens, the most commonly responsible agent of human babesiosis in France, but different.

Control of the patient's infectious status was performed 16 months later. Serology using the same antigen remained positive with a titer reduced to 1:128. PCR was negative.

\subsection{Analysis of $18 S$ rRNA Sequences and Position of Babesia sp. FR1 within the B. Divergens-Like Phylogenetic Group}

A 1641 bp sequence was obtained for Babesia sp. FR1, covering the positions that are discriminant among members of the $B$. divergens-like phylogenetic group: nucleotide positions $631,663,819$, and 1637 . The sequence is highly similar $(99.95 \%)$ to published Babesia sp. MO1-like and B. capreoli sequences, with only one nucleotide modification at position 819 and 663 respectively. It is also related to B. divergens (99.9\%) with two nucleotide substitutions at positions 631 and 1637 (Table 1).

Table 1. Biological and molecular features of the Babesia belonging to the B. divergens-like phylogenetic group.

\begin{tabular}{|c|c|c|c|c|c|c|c|c|}
\hline \multirow{2}{*}{ Organism } & \multirow{2}{*}{ Natural Host } & \multirow{2}{*}{$\begin{array}{l}\text { Human } \\
\text { Infection }\end{array}$} & \multirow{2}{*}{$\begin{array}{c}\text { Geographical } \\
\text { Occurence }\end{array}$} & \multirow{2}{*}{ Vector } & \multicolumn{4}{|c|}{$\begin{array}{l}\text { 18S rRNA Sequence Differences at } \\
\text { Nucleotide Position } b\end{array}$} \\
\hline & & & & & 631 & 663 & 819 & 1637 \\
\hline B. divergens & Cattle & + & Europe & I. ricinus & $\mathrm{A}$ & A & $\mathrm{T}$ & $\mathrm{C}$ \\
\hline B. capreoli & Roe deer & - & Europe & I. ricinus & G & $\mathrm{T}$ & $\mathrm{T}$ & $\mathrm{T}$ \\
\hline $\begin{array}{l}\text { Babesia sp. } \\
\text { MO1/AR1 }\end{array}$ & $\begin{array}{l}\text { Cottontail } \\
\text { rabbit }\end{array}$ & + & USA & I. dentatus a & G & $\mathrm{A}$ & $\mathrm{A}$ & $\mathrm{T}$ \\
\hline Babesia sp. FR1 & $\mathrm{nd}^{\mathrm{c}}$ & + & France & $\mathrm{nd}^{\mathrm{c}}$ & G & A & $\mathrm{T}$ & $\mathrm{T}$ \\
\hline
\end{tabular}

${ }^{a}$ likely vector according to [36]. ${ }^{b}$ corresponding to position described in [33]. ${ }^{c}$ not determined.

The sequence of $1643 \mathrm{bp}$ from the Arkansas case [35] obtained in this study (named Babesia sp. AR1) was 100\% identical to the first Babesia sp. MO1 case from Missouri (GenBank AY048113) [3], to the Kentucky case (GenBank AY887131) [34] and to the cottontail rabbit isolates [38]. They differ from $B$. divergens by three mutations at positions 631,819 and 1637 (99.8\% identity), and from B. capreoli by two mutations at positions 663 and 819 (99.9\% identity) (Table 1$)$.

\subsection{Major Differences in Ama-1 and Rap-1a Genes within the B. divergens-Like Phylogenetic Group}

Before analyzing the detailed sequence polymorphism of ama-1 and rap-1a genes between the $B$. divergens-like phylogenetic group members, some major differences in gene sequences appeared on the alignment (Figure 2).

Complete ama-1 sequences (sizes between 1803 and $1857 \mathrm{bp}$ ) were obtained in this study for four clonal lines of B. capreoli, for Babesia sp. FR1 and for Babesia sp. AR1, and were compared to $B$. divergens ama-1 sequences [45]. An $18 \mathrm{bp}$ sequence located between bases 553 and 570 was absent only in Babesia sp. AR1, corresponding probably to a deletion, which did not modify the translation frame (Supplementary Figure S1). Babesia sp. FR1 ama-1 sequence differs from all the others by an insertion of a $36 \mathrm{bp}$ sequence located between bases 1496 and 1531 . The inserted sequence is highly similar to an upstream 36 bp sequence (differing by two nucleotides) and seems therefore to correspond to a gene conversion event of this small gene portion. 


\begin{tabular}{cccccc}
\hline \multirow{2}{*}{ Gene } & \multirow{2}{*}{ B. divergens } & B. capreoli & Babesia sp. & Babesia sp. \\
& & AR1 & FR1 \\
\hline ama-1 & 18bp deletion & $\mathrm{N}$ & $\mathrm{N}$ & $\mathrm{Y}$ & $\mathrm{N}$ \\
& 36 bp duplication & $\mathrm{N}$ & $\mathrm{N}$ & $\mathrm{N}$ & $\mathrm{Y}$ \\
\hline \multirow{2}{*}{ rap-1a } & Copy number & 1 & 2 (id $95.9-96.4 \%)$ & 1 & 1 \\
& 3bp deletion & $\mathrm{N}$ & $\mathrm{N}$ & $\mathrm{Y}$ & $\mathrm{N}$ \\
& 33bp deletion & $\mathrm{Y}$ & $\mathrm{Y}$ and N & $\mathrm{N}$ & $\mathrm{N}$ \\
\hline
\end{tabular}

(a)

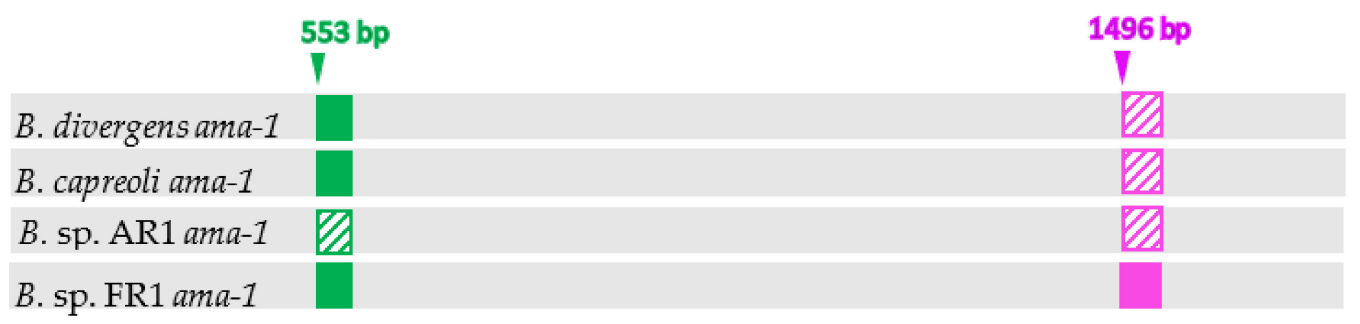

B. sp. FR1 ama-1

\section{B. divergens rap-1a \\ B. capreoli rap-1a1 \\ B. capreoli rap $-1 a 2$}

Babesia sp. AR1 rap-1a

Babesia sp. FR1 rap-1a

(b)

Figure 2. Major differences in ama-1 and rap-1a genes between members of the $B$. divergens-like phylogenetic group. (a) Copy number, and presence $(\mathrm{Y})$ or absence $(\mathrm{N})$ of insertion/deletion in ama-1 and rap-1a genes; (b) Schematic representation of the major differences and their positions in gene sequence. The colors used in the part (a) correspond to the colors used in the graphical representation of the corresponding deletions/insertions in the part (b). The deleted or absent regions are dashed.

Regarding the rap-1a gene, partial sequences (sizes between 1203 and $1236 \mathrm{bp}$ ) were obtained for four clonal lines of B. capreoli, for Babesia sp. FR1 and for Babesia sp. AR1, and were compared to $B$. divergens rap-1a sequences [46]. Comparison of rap-1a sequences from B. divergens, Babesia sp. AR1, and Babesia sp. FR1 highlighted a 3 bp deletion (nucleotides 1012 to 1014) in Babesia sp. AR1 only and a 33 bp deletion located between bases 1034 and 1066 in the 12 rap-1a B. divergens sequences performed, which did not modify the translation frame. As superposed chromatograms were observed for B. capreoli at the $3^{\prime}$ end of the rap-1a gene, the presence of multiple copies of this gene was suspected and confirmed by cloning/sequencing and subsequent specific amplifications of each gene copy from each of the four isolates. Two rap-1a gene copies were observed, which we named rap-1a1 and rap-1a2. The rap-1a1 copy was characterized by the absence of the two deletions, as found for Babesia sp. FR1. The rap-1a2 copy contained the $33 \mathrm{bp}$ deletion only and therefore resembled $B$. divergens rap- $1 a$.

These major deletions/insertions were not included in the sequence identity calculations, nor in the phylogenetic analyses, as they represent one-time, usually non-reversible events, with different evolutionary tempo and mode compared to substitutions.

\subsection{Intraspecific Sequence Diversity of Rap-1a and Ama-1 within B. divergens and B. capreoli}

The genetic variability within the $B$. divergens and $B$. capreoli strains have been analyzed previously for the $18 \mathrm{~S}$ rRNA gene and no variations were found [33]. 
Intraspecific genetic variability of $B$. divergens ama-1 and rap-1a genes was previously analyzed in studies performed at our lab and was found to be very low $[45,46]$. Sequence identities higher than $99.5 \%$ were highlighted for both genes, when comparing sequences of the same set of nine and twelve French isolates, for ama-1 and rap-1a respectively (Table 2 and Table S1). The ama-1 sequences showed between 99.9 to $100 \%$ conserved sites; two similar nucleotide substitutions were noted in ama-1 sequences of 1505B F14, 3601B E2 and Rouen 87 F5 isolates, compared to ama-1 sequences of the other six clonal lines. The rap-1a sequences showed sequence identities between 99.6 and $100 \%$, corresponding to a pairwise maximum of six nucleotide substitutions.

Table 2. Genetic variability of $18 \mathrm{~S}$ rRNA, ama-1 and rap-1a genes within B. divergens and B. capreoli.

\begin{tabular}{ccccc}
\hline Babesia Species & Gene & Number of Isolates & Nucleotide Differences & Identities \\
\hline \multirow{3}{*}{ B. divergens } & 18 S rRNA & 12 & None & $100 \%[33]$ \\
& rap-1a & 12 & $0-6 \mathrm{nt} / 1242 \mathrm{bp}$ & $99.6-100 \%[46]$ \\
& ama-1 & 9 & $0-2 \mathrm{nt} / 1821 \mathrm{bp}$ & $99.9-100 \%[45]$ \\
\hline \multirow{3}{*}{ B. capreoli } & $18 \mathrm{~S}$ rRNA & 9 & None & $100 \%[33]$ \\
& rap-1a1 & 4 & $0-7 \mathrm{nt} / 1236 \mathrm{bp}$ & $99.5-100 \%$ \\
& rap-1a2 & 4 & $0-5 \mathrm{nt} / 1203 \mathrm{bp}$ & $99.6-100 \%$ \\
\hline
\end{tabular}

In the case of B. capreoli, we analyzed the genetic polymorphism of ama-1 and rap-1a for four isolates collected and cultivated at our laboratory from previous studies $[33,47]$. The ama-1 sequences showed sequence identities between 99.7 to $100 \%$. The $2770 \mathrm{~F} 6$ and CVD08 005 ama-1 sequences were identical and up to nine polymorphic sites were identified resulting in six different nucleotide substitutions between ama-1 sequences of $2704 \mathrm{C}$ and 2801 F10 isolates, and were compared to the other two identical ama-1 sequences.

The two copies of the rap-1a gene (rap-1a1 and rap-1a2) were identified in all four $B$. capreoli isolates. Sequence variability of each gene copy was low (less than seven nucleotide substitutions), and identities ranged between $99.5-100 \%$ and between $99.6-100 \%$ among the rap-1a1 and the rap-1a2 sequences, respectively. Sequence identities between rap-1a1 and rap-1a2 copies ranged between 96.1 and $96.5 \%$. Most substitutions specific to each gene copy (39 positions) were non silent (39 substitutions resulting in 28 amino acid modifications), with a majority of substitutions on the first (nine substitutions) and/or second codon position (16 substitutions).

\subsection{Genetic Variability within the B. divergens-Like Phylogenetic Group}

As explained above, sequence identities were calculated without the regions corresponding to deletions/insertions and are presented as a contingency table including all three analyzed genes (Table 3). In general, the ama-1 gene seemed to be more conserved than the rap-1a gene as the percentage of sequence identities ranged between 94.3 to $98.7 \%$ for $a m a-1$ and between 86.6 to $98.7 \%$ for rap- $1 a$. For both genes, the lowest sequence identities were evidenced between $B$. divergens and all other analyzed Babesia within the group. The highest sequence identities for $a m a-1$ and rap- $1 a$ were obtained between Babesia sp. FR1 and Babesia sp. AR1 sequences (98.7\% identities for both genes). B. capreoli was found to be more closely related to Babesia sp. AR1 and Babesia sp. FR1 than to B. divergens.

It was not possible to determine if one of the two copies of $B$. capreoli rap-1a was more related to the unique rap-1a gene sequence of other members of the phylogenetic group, as sequence identity values were highly similar. 
Table 3. Contingency table for $18 \mathrm{~S}$ rRNA, rap-1a (partial cds) and ama-1 genes. For the $18 \mathrm{~S}$ rRNA sequences, the number of nucleotide differences between $18 \mathrm{~S}$ rRNA gene sequences are indicated in red, instead of the identity percentages. For $a m a-1$ and rap-1a genes, percentage of identities are indicated in green and blue, respectively. Sequence identities with each rap-1a copy (rap-1a1 and rap-1a2) are indicated. The identities are calculated excluding the deletions and duplication indicated in Figure 2. Accession numbers of sequences used to perform the analysis are indicated in supplementary Table S1.

\begin{tabular}{|c|c|c|c|c|}
\hline Organism & B. divergens & B. capreoli & Babesia sp. AR1 & Babesia sp. FR1 \\
\hline B. divergens & $\begin{array}{c}0 \\
99.9-100 \% \\
99.6-100 \%\end{array}$ & & & \\
\hline B. capreoli & $\begin{array}{c}3 \\
95-95.3 \% \\
\text { (rap-1a1) } 86.6-89.1 \% \\
\text { (rap1-a2) } 88.6-89.1 \%\end{array}$ & $\begin{array}{c}0 \\
\text { 99.7-100\% } \\
\text { (rap-1a1) } 99.5-100 \% \\
\text { (rap1-a2) } 99.6-100 \%\end{array}$ & & \\
\hline Babesia sp. AR1 & $\begin{array}{c}3 \\
94.3 \% \\
89.5-89.8 \%\end{array}$ & $\begin{array}{c}2 \\
\text { 97.2-97.3\% } \\
\text { (rap-1a1) } 95.1-95.4 \% \\
\text { (rap1-a2) } 95.3-95.7 \%\end{array}$ & $\begin{array}{c}0 \\
100 \% \\
100 \%\end{array}$ & \\
\hline Babesia sp. FR1 & $\begin{array}{c}2 \\
94.5 \% \\
89.8-90 \%\end{array}$ & $\begin{array}{c}1 \\
\text { 97.3-97.4\% } \\
\text { (rap-1a1) } 95.2-95.5 \% \\
\text { (rap1-a2) } 95.7-96.1 \%\end{array}$ & $\begin{array}{c}1 \\
98.7 \% \\
98.7 \%\end{array}$ & $\begin{array}{c}0 \\
100 \% \\
100 \%\end{array}$ \\
\hline
\end{tabular}

\subsection{Phylogenetic Analysis}

The phylogenetic analyses based on 18S rRNA, ama-1 and rap-1a genes were concordant and confirmed the placement of the Babesia sp. FR1 into the B. divergens-like phylogenetic group, with strong bootstrap values of 100 (Figures 3-5). According to the $18 \mathrm{~S}$ rRNA phylogenetic analysis, and despite the high level of conservation of this marker, two sister groups were supported by good bootstrap values, and Babesia sp. FR1 clustered with B. capreoli, Babesia sp. AR1 and Babesia sp. MO1 (bootstrap of 73), and not with $B$. divergens (forming the second cluster supported by a bootstrap value of 89) (Figure 3). The separation of these two clusters was also well supported in the phylogenetic analysis with ama-1 and rap-1a as markers (Figures 4 and 5). The B. divergens clade was supported by bootstrap values of 99 and 100 (ama-1 and rap-1a respectively). The B. capreoli/Babesia sp. AR1/Babesia sp. FR1 clade was also well supported by bootstrap values of 100 (ama-1 and rap-1a), but splits on the one hand into a subclade with B. capreoli (bootstraps of 100 and 83) and on the other hand into a second subclade with Babesia sp. FR1 and Babesia sp. AR1 (bootstraps of 100 and 99). The two Babesia capreoli rap-1a copies clustered into two sister groups with strong support (100). 


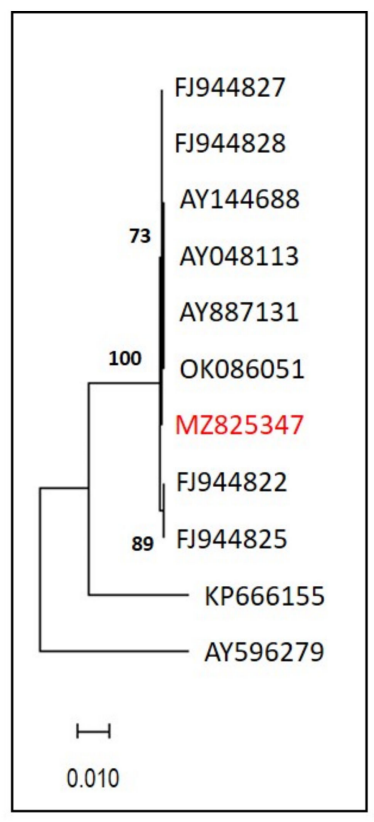

(a)

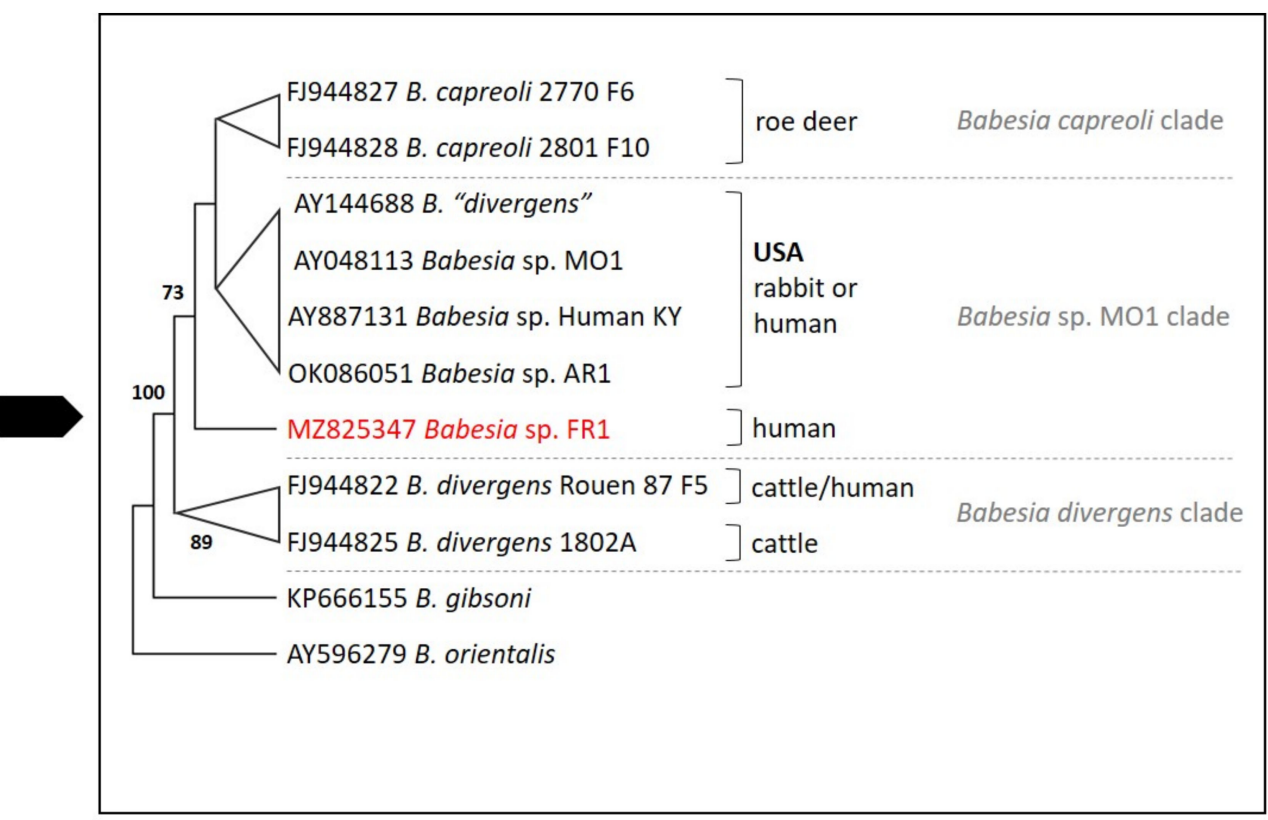

(b)

Figure 3. Maximum likelihood unrooted phylogenetic tree of Babesia from the Babesia divergens-like phylogenetic group based on partial $18 \mathrm{~S}$ rRNA sequences (1189 bp in the final data set). Branch support/bootstrap values are indicated at each node. Babesia sp. FR1 sequence obtained in this study is emphasized in red. (a) Scale bar indicates nucleotide substitution rate per site. (b) Topology of the tree allowing a better visualization of the bootstrap values; hosts of Babesia isolates are indicated.

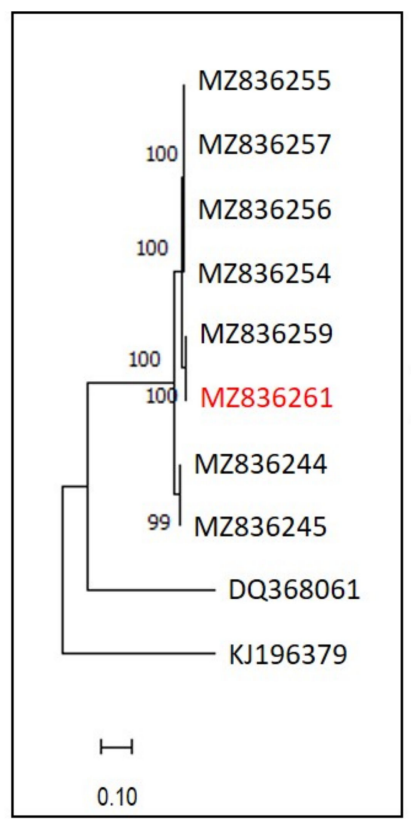

(a)

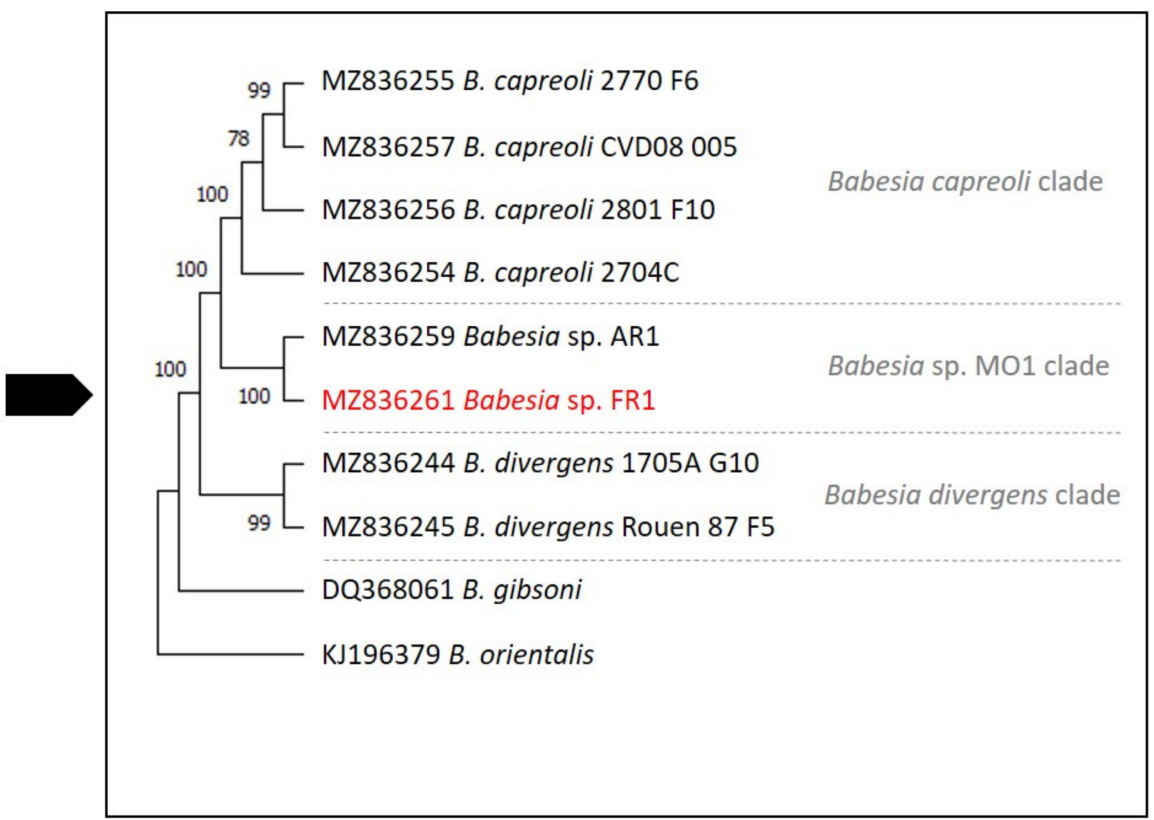

(b)

Figure 4. Maximum likelihood unrooted phylogenetic tree of Babesia from the Babesia divergens-like phylogenetic group based on partial ama-1 gene sequences (1728 bp in the final data set). Branch support/bootstrap values are indicated at each node. Babesia sp. FR1 sequence obtained in this study is emphasized in red. (a) Scale bar indicates nucleotide substitution rate per site. (b) Topology of the tree allowing a better visualization of the bootstrap values. 


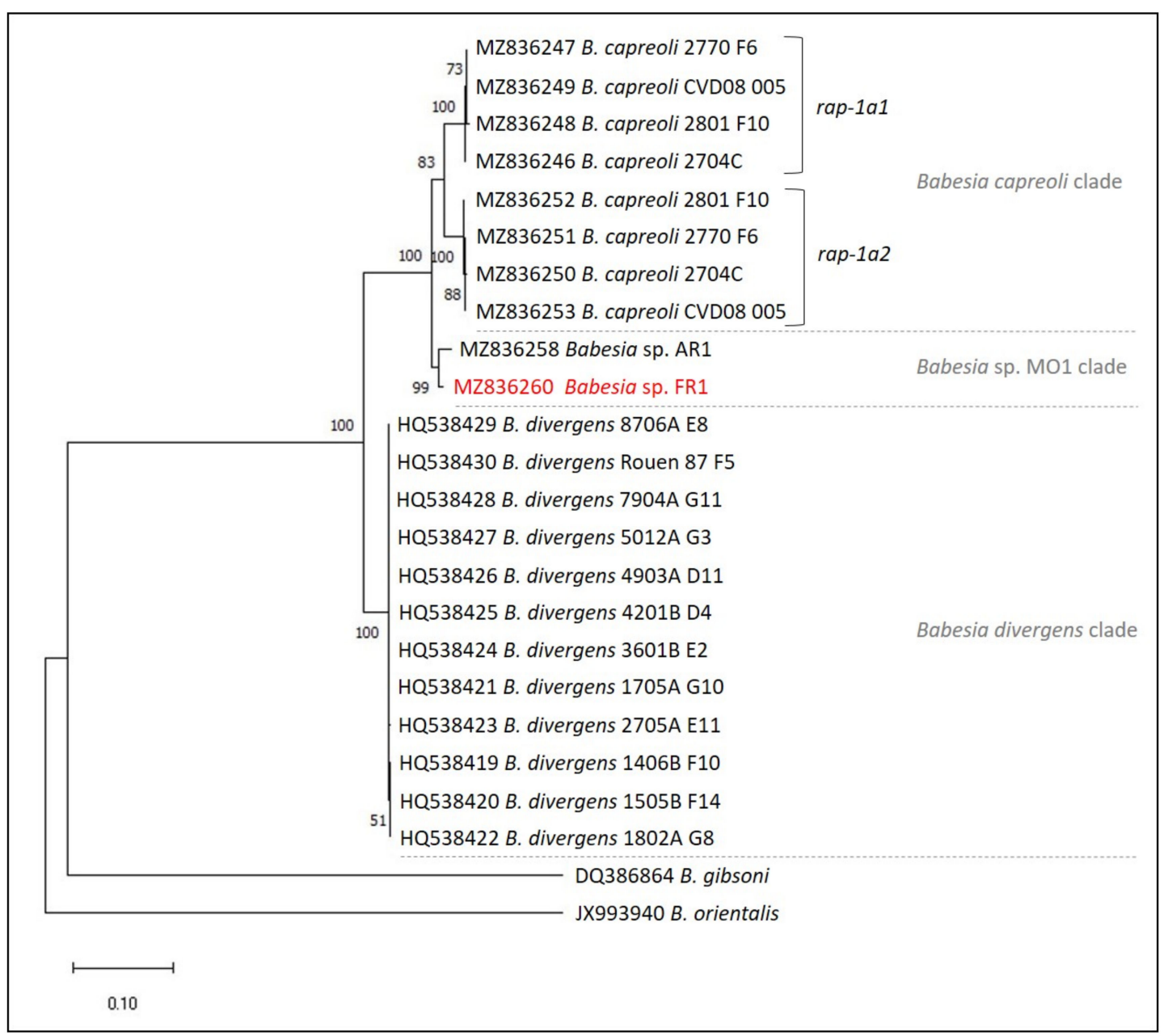

Figure 5. Maximum likelihood unrooted phylogenetic tree of Babesia from the Babesia divergens-like phylogenetic group based on partial rap-1a gene sequences (1138 bp in the final data set). Branch support/bootstrap values are indicated at each node. Babesia sp. FR1 sequence obtained in this study is emphasized in red. Scale bar indicates nucleotide substitution rate per site.

\section{Discussion}

Most human babesiosis cases are recorded in North America and are mainly due to Babesia microti, sporadically to B. duncani (Babesia sp. WA1) and to Babesia sp. MO1-like parasites. Sporadic cases were reported in Asia, Africa, and South America, with diverse and often partially characterized etiological agents [48]. In Europe, human babesiosis is rare and $B$. divergens is the main causal agent $[43,49]$. The most impacted countries are France, Ireland and Great Britain, and in France, Western regions and Normandy are most affected [10], due to substantial farming of bovines, the natural host of $B$. divergens [50].

The patient was most probably bitten by a tick on the Île de Ré, even if he had no recollection of a tick bite. This is the most probable place of tick acquisition by the patient, as it is close to a forest, where the abundance of the potential vector I. ricinus is high, increasing the risk of contracting tick-borne pathogens [51]. The patient was asplenic, which is also a major risk factor for severe or fatal babesiosis [10,43,49]. However, the symptoms in this patient developed slowly (two to three weeks between the onset of symptoms and admission to hospital) despite aspleny, while B. divergens' course of infection in such cases is usually fulminant [42]. Biological diagnosis of the provisionally named Babesia sp. FR1 was based on a blood smear, which led to the administration of antibabesial therapy (Atovaquone and Azithromycine) as soon as practicable. This treatment was effective, as 
symptoms rapidly disappeared, and parasite clearance was attested 16 months later by a negative PCR, correlated with a reduction of the serology titer.

Molecular characterization of Babesia sp. FR1 required a deeper analysis. Sequence and phylogenetic analysis of $18 \mathrm{~S}$ rRNA revealed that it was genetically close but different from typical $B$. divergens isolates infecting cattle or humans (two polymorphic sites at positions 831 and 1637) [33], but that it closely resembled the American B. divergens-like parasite Babesia sp. MO1. Despite the genetic difference with $B$. divergens, the infection could be diagnosed using $B$. divergens-specific serological tools (IFAT), confirming anyway a close relationship with $B$. divergens.

We decided to explore new markers to improve knowledge on the $B$. divergens-like phylogenetic clade and to correctly position this new isolate within this species complex. We chose rap-1a and ama-1 for two reasons. First, both genes code for proteins involved in the process of red blood cell invasion by the parasite [52], and as host range/specificity is an important biological feature in the description of this intra-erythrocytic obligatory parasite, they represent markers of interest. Second, we know from previous studies that both genes were well conserved among $B$. divergens isolates from cattle or humans $[45,46]$. Their interspecies divergence remained to be determined.

Regardless of the marker used, the sequences of $B$. divergens (cattle as a natural host) are grouped in a cluster well-separated from the other two clusters corresponding to $B$. capreoli and Babesia sp. MO1/AR1/FR1. Phylogenies based on more discriminant markers (rap-1a or ama-1) placed Babesia sp. FR1 in the cluster formed by isolates responsible for cases of human babesiosis in the USA represented by Babesia sp. AR1. This cluster is separated from the cluster of $B$. capreoli sequences, and from the cluster of $B$. divergens sequences. We can therefore conclude that Babesia sp. FR1 is not a B. divergens.

The phylogenetic group containing Babesia sp. MO1 is sometimes referred to as the $B$. divergens US lineage $[53,54]$. However, Babesia sp. FR1, which clusters with Babesia sp. MO1 and Babesia sp. AR1, was clearly acquired locally and is an autochthonous case as the patient did not travel to the USA in the months before the onset of the symptoms. Therefore, we not only confirm in the present study that Babesia sp. MO1-like sequences form a well-supported taxon, but we also highlight that the geographical distribution of this group is not restricted to the USA, but extends to Europe as it includes Babesia sp. FR1. The three clusters within Babesia divergens-like, i.e., B. divergens, B. capreoli, and Babesia sp. MO1like might be associated with their natural host rather than with geographic distribution. Humans are only incidental hosts for parasites belonging to the $B$. divergens-like group, the natural hosts being cattle for B. divergens, roe deer for B. capreoli and rabbits for Babesia sp. MO1. The natural host for Babesia sp. FR1 has not been characterized but could also well be a Laporidae, especially in the Île de Ré context, a highly touristic and populated island where cattle and cervids are rare or absent, due to limited forested areas dominated by resinous trees (mainly maritime pine trees) and typical local productions (vineyards and salt marshes). The European rabbit (Oryctolagus cuniculus) is highly abundant on this island where it has been pullulating since the 2000s, and could therefore be the potential natural host for Babesia sp. FR1.

In this study, we did not include isolates described as $B$. divergens in sika deer described in Japan or in humans in China $[6,53,54]$. Our goal in this study was to characterize and correctly place the new Babesia sp. FR1 isolate in the phylogenetic group of Babesia divergenslike, among biologically well-characterized isolates, i.e., whose host range has been studied and whose parasites have been cultured $[33,38-41,55]$. The isolates described in Japan from sika deer and named $B$. divergens are not included in the $B$. divergens-like phylogenetic group because they differ at the $18 \mathrm{~S}$ rRNA sequence from all other members of this group by at least six conserved substitutions all of which are different from those described within this group. These isolates form a sister group to $B$. divergens-like. The name $B$. divergens should be reserved for isolates from cattle or humans whose $18 \mathrm{~S}$ rRNA sequences match the many descriptions already published $[18-23,29,30,33,49]$. There is no evidence that isolates 
from sika deer are capable of infecting either cattle, gerbils (B. divergens experimental host), or humans.

The sequences named as "B. divergens" and described in humans in China [6] actually match those described for B. capreoli, with the characteristic differences at positions 631 and 663 [33]. This information raises the possibility of human infections by B. capreoli, a species that has never been molecularly characterized as responsible for symptomatic cases of human babesiosis in Europe and described as not growing in vitro in human red blood cells [33]. However, short-term asymptomatic carriage of parasites could occur in humans in geographic areas with high parasite and vector prevalences. We unsuccessfully attempted to obtain DNA from these parasites to include them in our study.

In the present study, we characterized rap-1a genes in the B. divergens-like phylogenetic group. The rap-1a genes belong to a multigene family, and multiple copies have already been demonstrated in a few Babesia species: two copies in B. bovis and B. canis, four to five in B. ovis, at least seven copies in Babesia sp. Xinjiang, eleven in B. bigemina and twelve in the B. motasi-like group members [52,56-61]. The multiple copies of rap-1a are usually different, allowing their differentiation, except in the case of $B$. divergens where the presence of two identical copies was highlighted when its genome was sequenced [52]. It is highly probable that two identical and therefore undistinguishable copies of rap-1a exist in all the $B$. divergens isolates characterized. We cannot exclude the presence of two identical copies also for members of the Babesia sp. MO1-like clade. In all B. capreoli isolates analyzed, two different but closely related rap-1a copies, named rap-1a1 and rap-1a2 (sequence identities of about $96 \%$ ) were identified. Each copy is equally different from either B. divergens, Babesia sp. FR1 or Babesia sp. AR1 rap-1a genes, and the two copies place as sister groups to each other, indicating a gene duplication that occurred after B. capreoli speciation. While genetic divergence occurred between the two rap-1a copies of $B$. capreoli, it was not the case between $B$. divergens rap-1a copies. B. divergens rap-1a gene has been previously characterized and its genetic variability among cattle and human isolates was found to be limited $[51,62,63]$. A greater sequence diversity among B. capreoli isolates compared to $B$. divergens was also highlighted in the case of the merozoite surface antigen $B c 37 / 41$ compared to $B d 37$, and a greater selection pressure was hypothesized [64]. This could also explain the sequence divergence between the two copies of rap-1a in $B$. capreoli and not between the two $B$. divergens copies of rap-1. But a more recent event of the rap-1a gene duplication in $B$. divergens could also explain the difference in sequence divergence between the two copies. Whether the last common ancestor of members of the $B$. divergens-like group possesses one or two copies of rap-1a, or when and how many times rap-1a gene duplication occurred in the speciation process is difficult to evaluate. Despite the presence of all motives that characterized RAP-1 family members, rap-1b sequence identity with the other two copies of rap- $1 a$ in the $B$. divergens genome is extremely low (45\%) and was not amplified with the primers used.

In conclusion, we describe here a case of human babesiosis in Europe (France) due to a Babesia isolate more closely related to the American Babesia sp. MO1 and AR1 than to $B$. divergens. Using two discriminant molecular markers, our study confirms the existence of three phylogenetic clades within the $B$. divergens-like group that would deserve the rank of species as their phylogenetic classification corresponds with their natural hosts; $B$. divergens natural host is cattle, $B$. capreoli infects mainly roe deer, and Babesia sp. MO1-like parasites probably infect Laporidae.

In Europe, diagnosis of human babesiosis is complicated due to its infrequency which often leads to a delayed detection and treatment. This delayed treatment promotes the development of a fulminant manifestation of this parasitic disease, in particular for asplenic or immunocompromised patients. Thus, the infection results often in the death of the patient, which could probably have been avoided by a more precocious diagnosis and treatment $[23,26]$. In Europe, the serological and molecular tools developed to diagnose $B$. divergens infections should principally be adequate to detect Babesia sp. FR1 infections. However, it needs to be taken into account that atypical immunofluorescence patterns (dots 
and weak fluorescence of the parasite surface) may lead to a negative conclusion when carrying out an immunofluorescence test. Prophylactic treatments are advised, such as wearing long clothes and performing skin examination for tick detection after exposure to high-risk environments.

\section{Materials and Methods}

\subsection{Babesia Isolates and DNA Origins}

A preliminary identification of Babesia sp. FR1 responsible for the mild form of babesiosis was performed on blood smears stained with May-Grünwald Giemsa. Further diagnosis was carried out by serology (IFAT with $B$. divergens antigen) [31], as well as 18S rRNA gene amplification [33] and sequencing from blood DNA extracted using the Nucleospin Blood kit according to the manufacturer's instructions (Macherey-Nagel, Düren, Germany).

B. capreoli isolates were collected and characterized in previous studies performed at our lab [33,47]. We included in our analysis four in vitro cultivated isolates from roe deer blood samples or spleen, from three different regions of France (Supplementary Table S1). $B$. divergens isolates were also cultivated in vitro from acute piroplasmosis cases in cows (11 isolates) or in humans (one isolate) [55].

DNA from cultured B. capreoli clonal lines (2704C, 2770 F6, 2801 F10 and CVD08 005) was extracted as previously mentioned.

DNA from one American case of human babesiosis was kindly provided by Mayo Medical Laboratory, Rochester, USA. This fatal case occurred in an asplenic patient, in Arkansas in 2015, with a possible acquisition through transfusion [35]. Due to its geographical origin, we named this isolate Babesia sp. AR1. It was characterized as a Babesia sp. MO1-like babesiosis etiological agent.

As all these isolates are very closely related to $B$. divergens, we have used throughout the manuscript the terminology $B$. divergens-like phylogenetic group to qualify the following isolates, species or clades: B. divergens, B. capreoli, Babesia sp. MO1, Babesia sp. AR1, and the new Babesia isolate, named Babesia sp. FR1.

\subsection{Comparison of $18 S$ rDNA Sequences within the B. divergens Taxonomic Group}

Babesia sp. AR1 $18 \mathrm{~S}$ rRNA sequences (560 bp) from the previously mentioned isolates were kindly provided by Mayo Medical Laboratory, Rochester, USA. Published B. capreoli as well as $B$. divergens $18 \mathrm{~S}$ rRNA sequences were used as a comparison [33]. Their origin and accession numbers are described in Supplementary Table S1. The partial 18S rRNA sequence of Babesia sp. FR1 was obtained using the same primers [33] (Table 4). With the aim of obtaining sequences of comparable sizes, the 18S rRNA partial sequence of Babesia sp. AR1 was also amplified with these primers and sequenced. The alignment was done using the ClustalW program as implemented in the Geneious R6 software (https:/ / www.geneious.com accessed on 1 October 2021).

\subsection{Amplification of Ama-1 (Apical Membrane Antigen-1) and Rap-1a (Rhoptry Associated protein-1) Genes for B. capreoli, Babesia sp. AR1, and Babesia sp. FR1}

PCR was performed to amplify the ama-1 and rap-1a genes of B. capreoli, Babesia sp. AR1, and Babesia sp. FR1 isolates using ama1-S1/ama1-R3 and rap1-fw/rap1-rev primers respectively (Table 4 ). Reactions were carried out in $30 \mu \mathrm{L}$ reaction mixtures containing 1 X GoTaq buffer, $4 \mathrm{mM} \mathrm{MgCl} 2,0.2 \mathrm{mM}$ of each dNTP (Eurobio Scientific, Les Ulis, France), 1 unit GoTaq G2 Flexi DNA Polymerase (Promega, Madison, WI, USA), $0.5 \mu \mathrm{M}$ of each primer and $1 \mu \mathrm{L}$ of DNA template. The amplification conditions comprised 5 min at $95{ }^{\circ} \mathrm{C}$ followed by 40 cycles of $30 \mathrm{~s}$ at $95^{\circ} \mathrm{C}, 30 \mathrm{~s}$ at the temperatures indicated in Table $4,1 \mathrm{~min}$ $30 \mathrm{~s}$ at $72{ }^{\circ} \mathrm{C}$, and a final extension at $72{ }^{\circ} \mathrm{C}$ for $5 \mathrm{~min}$. The amplified fragments were purified with the ExoSAP-IT reagent according to the manufacturer's instructions (Affymetrix, Santa Clara, CA, USA) and sequencing was performed on both strands (Eurofins Genomics, Ebersberg, Germany) using the same primers for rap-1a gene, or using primers distributed 
along the sequence for ama-1 gene (Table 4). Sequences were then assembled using the Geneious R6 software.

Table 4. Description of the primers used in this study for gene amplification as well as sequencing.

\begin{tabular}{|c|c|c|c|c|c|c|c|}
\hline $\begin{array}{l}\text { Target } \\
\text { Gene }\end{array}$ & $\begin{array}{l}\text { Primer } \\
\text { Name }\end{array}$ & Sequence $\left(5^{\prime}-3^{\prime}\right)$ & $\operatorname{Tm}\left({ }^{\circ} \mathrm{C}\right)$ & PCR & $\begin{array}{l}\text { Amplicon } \\
\text { Length (bp) }\end{array}$ & Sequencing & References \\
\hline \multirow[t]{2}{*}{ 18S rRNA } & $\begin{array}{l}\text { CRYPTOF } \\
\text { CRYPTOR }\end{array}$ & $\begin{array}{l}\text { AACCTGGTTGATCCTGCCAGTAGTCAT } \\
\text { TGATCCTTCTGCAGGTTCACCTA }\end{array}$ & 63 & $\begin{array}{l}x \\
\times\end{array}$ & 1728 & $\begin{array}{l}x \\
\times\end{array}$ & [33] \\
\hline & $\begin{array}{l}\text { BAB-GF2 } \\
\text { BAB-GR2 }\end{array}$ & $\begin{array}{l}\text { GTCTTGTAATTGGAATGATGG } \\
\text { CCAAAGACTTTGATTCTCT }\end{array}$ & 61 & $\begin{array}{l}\times \\
\times\end{array}$ & 560 & $\begin{array}{l}\bar{x} \\
\times\end{array}$ & {$[11]$} \\
\hline ama-1 & $\begin{array}{l}\text { ama1-S1 } \\
\text { ama1-R3 } \\
\text { ama1-As1 } \\
\text { ama1-S2 } \\
\text { ama1-As2 } \\
\text { ama1-S3 } \\
\text { ama1-As3 } \\
\text { ama1-S4 }\end{array}$ & $\begin{array}{c}\text { TGACTGCCATATCGACGAAG } \\
\text { CTCTAGTGAATTACGATAGC } \\
\text { GGCGGATATTCGGTTGAGG } \\
\text { CATGGCCAAGTTTGACCTTG } \\
\text { CTGCGTCACGCGTGAATTC } \\
\text { CTCCTGTGTATGGAGCCGA } \\
\text { GTGAAAGCGCGGTTGTGAC } \\
\text { AGCAGTTGGATCGCCTCTC }\end{array}$ & 61 & $\begin{array}{l}\times \\
\times\end{array}$ & $\approx 2000$ & $\begin{array}{l}\times \\
\times \\
\times \\
\times \\
\times \\
\times \\
\times \\
\times\end{array}$ & $\begin{array}{l}\text { this study } \\
\text { [50] } \\
\text { this study } \\
\text { this study } \\
\text { this study } \\
\text { this study } \\
\text { this study } \\
\text { this study }\end{array}$ \\
\hline rap-1a & $\begin{array}{l}\text { rap1-fw } \\
\text { rap1-rev }\end{array}$ & $\begin{array}{l}\text { AATGTCCTACTGGGAAACGC } \\
\text { GCGGAGTCCATGCCTGTACC }\end{array}$ & 58 & $\begin{array}{l}\times \\
\times \\
\end{array}$ & $\approx 1300$ & $\begin{array}{l}\times \\
\times \\
\times \\
\end{array}$ & $\begin{array}{l}\text { this study } \\
\text { this study }\end{array}$ \\
\hline rap-1a1 $\left(5^{\prime}\right)$ & $\begin{array}{l}\text { rap1-fw } \\
\text { rap1-a1-rev }\end{array}$ & GCTTAGTAGCATGCATCTTC & 58 & $\begin{array}{l}- \\
\times \\
\times\end{array}$ & 1146 & $-x_{-}^{-}$ & this study_ \\
\hline rap-1a1 ( $\left.3^{\prime}\right)$ & $\begin{array}{l}\text { rap1-a1-fw } \\
\text { rap1-rev }\end{array}$ & 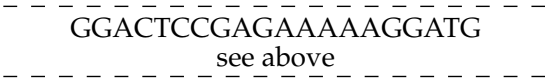 & 58 & $\bar{x}$ & 261 & $-\bar{x}-$ & $\overline{\text { this study }}$ \\
\hline rap-1a2 $\left(5^{\prime}\right)$ & $\begin{array}{l}\text { rap1-fw } \\
\text { rap1-a2-rev }\end{array}$ & TGGAACAACTTCTTCATAGG & 58 & $\begin{array}{l}-\bar{x} \\
\times \\
x\end{array}$ & $\begin{array}{ll}--- \\
1123 \\
---\end{array}$ & $\begin{array}{l}\bar{x}-- \\
x \\
x\end{array}$ & this study \\
\hline rap-1a2 ( $\left.3^{\prime}\right)$ & $\begin{array}{l}\text { rap1-a2-fw } \\
\text { rap1-rev }\end{array}$ & 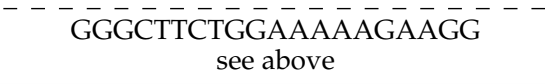 & 58 & $\begin{array}{l}\bar{x} \\
\times\end{array}$ & 228 & $\begin{array}{l}\bar{x}-- \\
x\end{array}$ & this study \\
\hline
\end{tabular}

For the four isolates of B. capreoli (2704C, 2770 F6, 2801 F10 and CVD08 005), preliminary sequencing results of rap-1a gene highlighted superposed chromatograms at the gene $3^{\prime}$ end, suggesting the presence of multiple copies of this gene, a frequent feature for this gene. The PCR products were therefore cloned in the pGEM-T easy vector according to the manufacturer's instructions (Promega, Madison, WI, USA), to determine the number and sequences of the putative different copies of the rap-1a gene. Escherichia coli strain BL21 was transformed with the plasmid constructions and colonies with the expected inserts were selected by direct colony PCR using vector primers: T7 and SP6. Recombinant plasmids were then isolated using the Nucleospin Plasmid kit (Macherey-Nagel, Düren, Germany) and both strands of the inserts were sequenced using vector primers (Eurofins, Genomics, Ebersberg, Germany). Then primers were designed to selectively amplify the different rap-1a gene copies of $B$. capreoli isolates (Table 4). Primers rap1-a1-fw or rap1-a2-fw were associated with primer rap1-rev to amplify the $3^{\prime}$ part of respective rap-1a copies. Primers rap1-a1-rev or rap1-a2-rev were associated with primer rap1-fw to amplify the $5^{\prime}$ part of rap-1a copies (same reaction and cycling conditions as above). PCR products were purified and sequenced as already mentioned.

\subsection{Comparison of Ama-1 and Rap-1a DNA Sequences for B. divergens-Like Phylogenetic Group Members}

The resulting ama-1 and rap-1a DNA sequences of B. capreoli, Babesia sp. AR1 and Babesia sp. FR1 were aligned along with the published $a m a-1$ and rap-1a DNA sequences of $B$. divergens isolates using the ClustalW program as implemented in the Geneious R6 software.

\subsection{Phylogenetic Analysis}

Phylogenetic relationships within the Babesia divergens-like group were inferred using published sequences available in GenBank (Supplementary Table S1) and sequence data produced in the present study (18S rRNA, ama-1 and rap-1a sequences). Sequences were aligned using Muscle as implemented in MEGA version X [65]. Phylogenetic analyses used a trimmed alignment of $1189 \mathrm{bp}$ with complete deletion option for the 18S rRNA gene, 
$1728 \mathrm{bp}$ and $1138 \mathrm{bp}$ with complete deletion option for the ama-1 and rap-1a coding sequences respectively. Maximum likelihood phylogenetic trees were produced using MEGA$X$, with 1000 bootstrap replications based on the Tamura 3-parameter model [66] for the $18 \mathrm{~S}$ rRNA gene and the ama-1 gene, and based on the Kimura 2-parameter model [67] model for rap-1a gene. For the ama-1 and rap-1a sequences, the three codon positions were included. The appropriate model of nucleotide substitution for ML analysis was selected based on the Bayesian Information Criterion (BIC) computed by MEGA-X.

\subsection{Genbank Deposition}

Nucleotidic sequences obtained in this study were submitted to GenBank with accession numbers MZ825347 and OK086051 for the 18S rRNA sequence of Babesia sp. FR1 and Babesia sp. AR1 respectively, MZ836259 and MZ836261 for the ama-1 sequences of Babesia sp. AR1 and Babesia sp. FR1 respectively, MZ836258 and MZ836260 for the rap-1a sequences of Babesia sp. AR1 and Babesia sp. FR1 respectively. Accession numbers for rap-1a and ama-1 sequences of B. capreoli are presented in Supplementary Table S1.

Supplementary Materials: The following are available online at https:/ / www.mdpi.com/article/ 10.3390/pathogens10111433/s1, Table S1: Description of B. divergens (A) and B. capreoli (B) clonal lines used in the study and Genbank accession numbers. Figure S1: (A) Major differences in ama-1 gene and AMA-1 protein sequences. (B) Major differences in rap-1a gene and RAP-1A protein sequences.

Author Contributions: Conceptualization, L.M. and M.-C.d.C.; methodology, C.B. and F.M.; validation, C.B., N.d.l.C. and L.M.; formal analysis, C.B.; investigation, C.B., V.P. and M.-C.d.C.; resources, V.P., F.M., M.-C.d.C. and L.M.; data curation, C.B.; writing-original draft preparation, C.B., M.-C.d.C. and L.M.; writing-review and editing, C.B., M.-C.d.C., N.d.l.C., F.M. and V.P..; visualization, F.M., C.B. and L.M.; supervision, L.M.; project administration, L.M.; funding acquisition, C.B., N.d.l.C. and L.M. All authors have read and agreed to the published version of the manuscript.

Funding: This research received no external funding.

Institutional Review Board Statement: Ethical review and approval were waived for this study, because this case report did not involve human subject research.

Informed Consent Statement: Written informed consent has been obtained from the patient to publish this paper.

Acknowledgments: The authors wish to thank M. Jouglin for technical support.

Conflicts of Interest: The authors declare no conflict of interest.

\section{References}

1. Schnittger, L.; Rodriguez, A.E.; Florin-Christensen, M.; Morrison, D.A. Babesia: A world emerging. Infect. Genet. Evol. 2012, 12, 1788-1809. [CrossRef] [PubMed]

2. Herwaldt, B.L.; de Bruyn, G.; Pieniazek, N.J.; Homer, M.; Lofy, K.H.; Slemenda, S.B.; Fritsche, T.R.; Persing, D.H.; Limaye, A.P. Babesia divergens-like infection, Washington State. Emerg. Infect. Dis. 2004, 10, 622-629. [CrossRef]

3. Herwaldt, B.; Persing, D.H.; Précigout, E.A.; Goff, W.L.; Mathiesen, D.A.; Taylor, P.W.; Eberhard, M.L.; Gorenflot, A.F. A fatal case of babesiosis in Missouri: Identification of another piroplasm that infects humans. Ann. Intern. Med. 1996, 124, 643-650. [CrossRef] [PubMed]

4. Vannier, E.G.; Diuk-Wasser, M.A.; Ben Mamoun, C.; Krause, P.J. Babesiosis. Infect. Dis. Clin. N. Am. 2015, 29, 357-370. [CrossRef]

5. Jiang, J.F.; Zheng, Y.C.; Jiang, R.R.; Li, H.; Huo, Q.B.; Jiang, B.G.; Sun, Y.; Jia, N.; Wang, Y.W.; Ma, L.; et al. Epidemiological, clinical, and laboratory characteristics of 48 cases of "Babesia venatorum" infection in China: A descriptive study. Lancet Infect. Dis. 2015, 15, 196-203. [CrossRef]

6. Wang, J.; Zhang, S.; Yang, J.; Liu, J.; Zhang, D.; Li, Y.; Luo, J.; Guan, G.; Yin, H. Babesia divergens in human in Gansu province, China. Emerg. Microbes Infect. 2019, 8, 959-961. [CrossRef] [PubMed]

7. Jia, N.; Zheng, Y.C.; Jiang, J.F.; Jiang, R.R.; Jiang, B.G.; Wei, R.; Liu, H.B.; Huo, Q.B.; Sun, Y.; Chu, Y.L.; et al. Human babesiosis caused by a Babesia crassa-like pathogen: A case series. Clin. Infect. Dis. 2018, 67, 1110-1119. [CrossRef]

8. Skrabalo, Z.; Deanovic, Z. Piroplasmosis in man; report of a case. Doc. Med. Geogr. Trop. 1957, 9, 11-16. [PubMed]

9. Gray, J.S. Identity of the causal agents of human babesiosis in Europe. Int. J. Med. Microbiol. 2006, 296, 131-136. [CrossRef]

10. Uguen, C.; Girard, L.; Brasseur, P.; Leblay, R. Human babesiosis in 1997. Rev. Med. Interne 1997, 18, 945-951. [CrossRef] 
11. Herwaldt, B.L.; Cacciò, S.; Gherlinzoni, F.; Aspöck, H.; Slemenda, S.B.; Piccaluga, P.; Martinelli, G.; Edelhofer, R.; Hollenstein, U.; Poletti, G.; et al. Molecular characterization of a non-Babesia divergens organism causing zoonotic babesiosis in Europe. Emerg. Infect. Dis. 2003, 9, 942-948. [CrossRef]

12. Häselbarth, K.; Tenter, A.M.; Brade, V.; Krieger, G.; Hunfeld, K.P. First case of human babesiosis in Germany-Clinical presentation and molecular characterisation of the pathogen. Int. J. Med. Microbiol. 2007, 297, 197-204. [CrossRef] [PubMed]

13. Bläckberg, J.; Lazarevic, V.L.; Hunfeld, K.P.; Persson, K.E.M. Low-virulent Babesia venatorum infection masquerading as hemophagocytic syndrome. Ann. Hematol. 2018, 97, 731-733. [CrossRef] [PubMed]

14. Stahl, P.; Poinsignon, Y.; Pouedras, P.; Ciubotaru, V.; Berry, L.; Emu, B.; Krause, P.J.; Ben Mamoun, C.; Cornillot, E. Case report of the patient source of the Babesia microti R1 reference strain and implications for travelers. J. Travel. Med. 2018, 25, tax073. [CrossRef] [PubMed]

15. Hildebrandt, A.; Hunfeld, K.P.; Baier, M.; Krumbholz, A.; Sachse, S.; Lorenzen, T.; Kiehntopf, M.; Fricke, H.J.; Straube, E. First confirmed autochthonous case of human Babesia microti infection in Europe. Eur. J. Clin. Microbiol. Infect. Dis. 2007, 26, 595-601. [CrossRef]

16. Centeno-Lima, S.; do Rosário, V.; Parreira, R.; Maia, A.J.; Freudenthal, A.M.; Nijhof, A.M.; Jongejan, F. A fatal case of human babesiosis in Portugal: Molecular and phylogenetic analysis. Trop. Med. Int. Health. 2003, 8, 760-764. [CrossRef] [PubMed]

17. Corpelet, C.; Vacher, P.; Coudore, F.; Laurichesse, H.; Conort, N.; Souweine, B. Role of quinine in life-threatening Babesia divergens infection successfully treated with clindamycin. Eur. J. Clin. Microbiol. Infect. Dis. 2005, 24, 74-75. [CrossRef]

18. Haapasalo, K.; Suomalainen, P.; Sukura, A.; Siikamaki, H.; Jokiranta, T.S. Fatal babesiosis in man, Finland, 2004. Emerg. Infect. Dis. 2010, 16, 1116-1118. [CrossRef]

19. Gonzalez, L.M.; Rojo, S.; Gonzalez-Camacho, F.; Luque, D.; Lobo, C.A.; Montero, E. Severe babesiosis in immunocompetent man, Spain, 2011. Emerg. Infect. Dis. 2014, 20, 724-726. [CrossRef]

20. González, L.M.; Castro, E.; Lobo, C.A.; Richart, A.; Ramiro, R.; González-Camacho, F.; Luque, D.; Velasco, A.C.; Montero, E. First report of Babesia divergens infection in an HIV patient. Int. J. Infect. Dis. 2015, 33, 202-204. [CrossRef] [PubMed]

21. Tanyel, E.; Guler, N.; Hokelek, M.; Ulger, F.; Sunbul, M. A case of severe babesiosis treated successfully with exchange transfusion. Int. J. Infect. Dis. 2015, 38, 83-85. [CrossRef] [PubMed]

22. O'Connell, S.; Lyons, C.; Abdou, M.; Patowary, R.; Aslam, S.; Kinsella, N.; Zintl, A.; Hunfeld, K.P.; Wormser, G.P.; Gray, J.; et al. Splenic dysfunction from celiac disease resulting in severe babesiosis. Ticks Tick Borne Dis. 2017, 8, 537-539. [CrossRef]

23. Asensi, V.; González, L.M.; Fernández-Suárez, J.; Sevilla, E.; Navascués, R.Á.; Suárez, M.L.; Lauret, M.E.; Bernardo, A.; Carton, J.A.; Montero, E. A fatal case of Babesia divergens infection in Northwestern Spain. Ticks Tick Borne Dis. 2018, 9, 730-734. [CrossRef]

24. Kukina, I.V.; Zelya, O.P.; Guzeeva, T.M.; Karan, L.S.; Perkovskaya, I.A.; Tymoshenko, N.I.; Guzeeva, M.V. Severe babesiosis caused by Babesia divergens in a host with intact spleen, Russia, 2018. Ticks Tick Borne Dis. 2019, 10, 101262. [CrossRef]

25. Mørch, K.; Holmaas, G.; Frolander, P.S.; Kristoffersen, E.K. Severe human Babesia divergens infection in Norway. Int. J. Infect. Dis. 2015, 33, 37-38. [CrossRef] [PubMed]

26. Kukina, I.V.; Guzeeva, T.M.; Zelya, O.P.; Ganushkina, L.A. Fatal human babesiosis caused by Babesia divergens in an asplenic host. IDCases 2018, 13, e00414. [CrossRef]

27. Strizova, Z.; Havlova, K.; Patek, O.; Smrz, D.; Bartunkova, J. The first human case of babesiosis mimicking Reiter's syndrome. Folia Parasitol. 2020, 67, 1-5. [CrossRef]

28. Loutan, L.; Rossier, J.; Zufferey, G.; Cuénod, D.; Hatz, C.; Marti, H.P.; Gern, L. Human babesiosis: First case report in Switzerland. Rev. Med. Suisse Romande 1994, 114, 111-116. (In French)

29. Martinot, M.; Zadeh, M.M.; Hansmann, Y.; Grawey, I.; Christmann, D.; Aguillon, S.; Jouglin, M.; Chauvin, A.; De Briel, D. Babesiosis in immunocompetent patients, Europe. Emerg. Infect. Dis. 2011, 17, 114-116. [CrossRef]

30. Paleau, A.; Candolfi, E.; Souply, L.; De Briel, D.; Delarbre, J.M.; Lipsker, D.; Jouglin, M.; Malandrin, L.; Hansmann, Y.; Martinot, M. Human babesiosis in Alsace. Med. Mal. Infect. 2020, 50, 486-491. [CrossRef] [PubMed]

31. Lempereur, L.; Shiels, B.; Heyman, P.; Moreau, E.; Saegerman, C.; Losson, B.; Malandrin, L. A retrospective serological survey on human babesiosis in Belgium. Clin. Microbiol. Infect. 2015, 21, 96.e1-96.e7. [CrossRef]

32. Duh, D.; Petrovec, M.; Bidovec, A.; Avsic-Zupanc, T. Cervids as Babesiae hosts, Slovenia. Emerg. Infect. Dis. 2005, 11, 1121-1123. [CrossRef]

33. Malandrin, L.; Jouglin, M.; Sun, Y.; Brisseau, N.; Chauvin, A. Redescription of Babesia capreoli (Enigk and Friedhoff, 1962) from roe deer (Capreolus capreolus): Isolation, cultivation, host specificity, molecular characterisation and differentiation from Babesia divergens. Int. J. Parasitol. 2010, 40, 277-284. [CrossRef]

34. Beattie, J.F.; Michelson, M.L.; Holman, P.J. Acute babesiosis caused by Babesia divergens in a resident of Kentucky. N. Engl. J. Med. 2002, 347, 697-698. [CrossRef]

35. Burgess, M.J.; Rosenbaum, E.R.; Pritt, B.S.; Haselow, D.T.; Ferren, K.M.; Alzghoul, B.N.; Rico, J.C.; Sloan, L.M.; Ramanan, P.; Purushothaman, R.; et al. Possible transfusion-transmitted Babesia divergens-like/MO1 infection in an Arkansas patient. Clin. Infect. Dis. 2017, 64, 1622-1625. [CrossRef]

36. Herc, E.; Pritt, B.; Huizenga, T.; Douce, R.; Hysell, M.; Newton, D.; Sidge, J.; Losman, E.; Sherbeck, J.; Kaul, D.R. Probable locally acquired Babesia divergens-like infection in woman, Michigan, USA. Emerg. Infect. Dis. 2018, 24, 1558-1560. [CrossRef] [PubMed]

37. Goethert, H.K.; Telford, S.R., 3rd. Enzootic transmission of Babesia divergens among cottontail rabbits on Nantucket Island, Massachusetts. Am. J. Trop. Med. Hyg. 2003, 69, 455-460. [CrossRef] [PubMed] 
38. Holman, P.J.; Spencer, A.M.; Droleskey, R.E.; Goethert, H.K.; Telford, S.R., 3rd. In vitro cultivation of a zoonotic Babesia sp. isolated from eastern cottontail rabbits (Sylvilagus floridanus) on Nantucket Island, Massachusetts. J. Clin. Microbiol. 2005, 43, 3995-4001. [CrossRef]

39. Holman, P.J.; Spencer, A.M.; Telford, S.R., 3rd; Goethert, H.K.; Allen, A.J.; Knowles, D.P.; Goff, W.L. Comparative infectivity of Babesia divergens and a zoonotic Babesia divergens-like parasite in cattle. Am. J. Trop. Med. Hyg. 2005, 73, 865-870. [CrossRef] [PubMed]

40. Spencer, A.M.; Goethert, H.K.; Telford, S.R., 3rd; Holman, P.J. In vitro host erythrocyte specificity and differential morphology of Babesia divergens and a zoonotic Babesia sp. from eastern cottontail rabbits (Sylvilagus floridanus). J. Parasitol. 2006, 92, 333-340. [CrossRef]

41. Holman, P.J. Phylogenetic and biologic evidence that Babesia divergens is not endemic in the United States. Ann. N. Y. Acad. Sci. 2006, 1081, 518-525. [CrossRef]

42. Hildebrandt, A.; Gray, J.S.; Hunfeld, K.P. Human babesiosis in Europe: What clinicians need to know. Infection 2013, 41, 1057-1072. [CrossRef]

43. Hildebrandt, A.; Zintl, A.; Montero, E.; Hunfeld, K.P.; Gray, J. Human Babesiosis in Europe. Pathogens 2021, 10, 1165. [CrossRef]

44. Jahfari, S.; Hofhuis, A.; Fonville, M.; van der Giessen, J.; van Pelt, W.; Sprong, H. Molecular Detection of tick-borne pathogens in humans with tick bites and erythema migrans, in the Netherlands. PLoS Negl. Trop. Dis. 2016, 10, e0005042. [CrossRef]

45. Moreau, E.; Bonsergent, C.; Al Dybiat, I.; Gonzalez, L.M.; Lobo, C.A.; Montero, E.; Malandrin, L. Babesia divergens apical membrane antigen-1 (BdAMA-1): A poorly polymorphic protein that induces a weak and late immune response. Exp. Parasitol. 2015, 155, 40-45. [CrossRef]

46. Sun, Y. Caractérisation moléculaire, localisation cellulaire et conservation des protéines impliquées dans le processus d'invasion des érythrocytes par Babesia divergens. Ph.D. Thesis, Nantes University, Nantes, France, 2010; 202p.

47. Bastian, S.; Jouglin, M.; Brisseau, N.; Malandrin, L.; Klegou, G.; L'Hostis, M.; Chauvin, A. Antibody prevalence and molecular identification of Babesia spp. in roe deer in France. J. Wildl. Dis. 2012, 48, 416-424. [CrossRef] [PubMed]

48. Krause, P.J. Human babesiosis. Int. J. Parasitol. 2019, 49, 165-174. [CrossRef]

49. Gorenflot, A.; Moubri, K.; Precigout, E.; Carcy, B.; Schetters, T.P. Human babesiosis. Ann. Trop. Med. Parasitol. 1998, 92, 489-501. [CrossRef] [PubMed]

50. L'Hostis, M.; Chauvin, A.; Valentin, A.; Marchand, A.; Gorenflot, A. Large scale survey of bovine babesiosis due to Babesia divergens in France. Vet. Rec. 1995, 136, 36-38. [CrossRef]

51. Agoulon, A.; Malandrin, L.; Lepigeon, F.; Vénisse, M.; Bonnet, S.; Becker, C.A.; Hoch, T.; Bastian, S.; Plantard, O.; Beaudeau, F. A Vegetation Index qualifying pasture edges is related to Ixodes ricinus density and to Babesia divergens seroprevalence in dairy cattle herds. Vet. Parasitol. 2012, 185, 101-109. [CrossRef] [PubMed]

52. González, L.M.; Estrada, K.; Grande, R.; Jiménez-Jacinto, V.; Vega-Alvarado, L.; Sevilla, E.; Barrera, J.; Cuesta, I.; Zaballos, Á.; Bautista, J.M.; et al. Comparative and functional genomics of the protozoan parasite Babesia divergens highlighting the invasion and egress processes. PLoS Negl. Trop. Dis. 2019, 13, e0007680. [CrossRef]

53. Zamoto-Niikura, A.; Tsuji, M.; Imaoka, K.; Kimura, M.; Morikawa, S.; Holman, P.J.; Hirata, H.; Ishihara, C. Sika deer carrying Babesia parasites closely related to B. divergens, Japan. Emerg. Infect. Dis. 2014, 20, 1398-1400. [CrossRef]

54. Zamoto-Niikura, A.; Tsuji, M.; Qiang, W.; Morikawa, S.; Hanaki, K.I.; Holman, P.J.; Ishihara, C. The Babesia divergens Asia lineage is maintained through enzootic cycles between Ixodes persulcatus and sika deer in Hokkaido, Japan. Appl. Environ. Microbiol. 2018, 84, e02491-17. [CrossRef] [PubMed]

55. Malandrin, L.; L'Hostis, M.; Chauvin, A. Isolation of Babesia divergens from carrier cattle blood using in vitro culture. Vet. Res. 2004, 35, 131-139. [CrossRef]

56. Dalrymple, B.P.; Casu, R.E.; Peters, J.M.; Dimmock, C.M.; Gale, K.R.; Böse, R.; Wright, I.G. Characterisation of a family of multi-copy genes encoding rhoptry protein homologues in Babesia bovis, Babesia ovis and Babesia canis. Mol. Biochem. Parasitol. 1993, 57, 181-192. [CrossRef]

57. Suarez, C.E.; Palmer, G.H.; Hötzel, I.; McElwain, T.F. Structure, sequence, and transcriptional analysis of the Babesia bovis rap-1 multigene locus. Mol. Biochem. Parasitol. 1998, 93, 215-224. [CrossRef] [PubMed]

58. Suarez, C.E.; Palmer, G.H.; Florin-Christensen, M.; Hines, S.A.; Hötzel, I.; McElwain, T.F. Organization transcription, and expression of rhoptry associated protein genes in the Babesia bigemina rap-1 locus. Mol. Biochem. Parasitol. 2003, 127, 101-112. [CrossRef]

59. Niu, Q.; Bonsergent, C.; Guan, G.; Yin, H.; Malandrin, L. Sequence and organization of the rhoptry-associated-protein-1 (rap-1) locus for the sheep hemoprotozoan Babesia sp. BQ1 Lintan (B. motasi phylogenetic group). Vet. Parasitol. 2013, $198,24-38$. [CrossRef]

60. Niu, Q.; Valentin, C.; Bonsergent, C.; Malandrin, L. Strong conservation of rhoptry-associated-protein-1 (RAP-1) locus organization and sequence among Babesia isolates infecting sheep from China (Babesia motasi-like phylogenetic group). Infect. Genet. Evol. 2014, 28, 21-32. [CrossRef]

61. Niu, Q.; Marchand, J.; Yang, C.; Bonsergent, C.; Guan, G.; Yin, H.; Malandrin, L. Rhoptry-associated protein (rap-1) genes in the sheep pathogen Babesia sp. Xinjiang: Multiple transcribed copies differing by $3^{\prime}$ end repeated sequences. Vet. Parasitol. 2015, 211, 158-169. [CrossRef] 
62. Skuce, P.J.; Mallon, T.R.; Taylor, S.M. Molecular cloning of a putative rhoptry associated protein homologue from Babesia divergens. Mol. Biochem. Parasitol. 1996, 77, 99-102. [CrossRef]

63. Rodriguez, M.; Alhassan, A.; Ord, R.L.; Cursino-Santos, J.R.; Singh, M.; Gray, J.; Lobo, C.A. Identification and characterization of the RouenBd1987 Babesia divergens Rhopty-Associated Protein 1. PLoS ONE 2014, 9, e107727. [CrossRef]

64. Sun, Y.; Jouglin, M.; Bastian, S.; Chauvin, A.; Malandrin, L. Molecular cloning and genetic polymorphism of Babesia capreoli gene Bcp37/41, an ortholog of Babesia divergens merozoite surface antigen Bd37. Vet. Parasitol. 2011, 178, 184-191. [CrossRef] [PubMed]

65. Kumar, S.; Stecher, G.; Li, M.; Knyaz, C.; Tamura, K. MEGA X: Molecular evolutionary genetics analysis across computing platforms. Mol. Biol. Evol. 2018, 35, 1547-1549. [CrossRef] [PubMed]

66. Tamura, K. Estimation of the number of nucleotide substitutions when there are strong transition-transversion and $\mathrm{G}+\mathrm{C}-\mathrm{content}$ biases. Mol. Biol. Evol. 1992, 9, 678-687. [CrossRef]

67. Kimura, M. A simple method for estimating evolutionary rate of base substitutions through comparative studies of nucleotide sequences. J. Mol. Evol. 1980, 16, 111-120. [CrossRef] [PubMed] 